\title{
REE patterns as a tool for recognition of diagenetic beds: a case from the Lower Devonian Upper Gaspé Limestones, Gaspé Peninsula, Québec
}

\author{
Denis Lavoie \\ Centre Géoscientifique de Québec, Geological Survey of Canada \\ and \\ Mario Bergeron \\ Centre Géoscientifique de Québec, INRS-Géoressources \\ 2700 Einstein Street, P.O. Box 7500, Ste-Foy, Québec G1V 4C7, Canada \\ Date Received October 14, 1992 \\ Date Accepted March 9, 1993
}

\begin{abstract}
Analyses of rare earth elements (REE), major elements, insoluble residue content and mineralogy were performed on carbonate and siliciclastic samples from the Early Devonian Upper Gaspé Limestones in eastem Gaspé Peninsula. Siliciclastic rocks are richer in REE than coeval mechanically deposited carbonates. A positive relationship between the absolute amount of REE and the content of aluminosilicate is clear for most samples. Even if poor in aluminosilicate, diagenetic carbonate concretions are the richest in REE. The concretions also show a significant negative Europium anomaly. Mineralogical, major element and stable isotope data show that calcite cementation resulting in the concretions was rapid and completed before reaching the methanogenic zone. Diagenetic conditions were responsible for remobilization of the REE from host detrital material and for raising the REE content of the concretions. The REE pattern is a potential tool for recognition of diagenetic beds produced in various geochemical environments.
\end{abstract}

Une étude du contenu en terres rares (TR), de la géochimie des éléments majeurs et de la teneur et minéralogie des résidus insolubles fut menée sur des échantillons de carbonates et silicoclastites provenant des Calcaires supérieurs de Gaspé (Dévonien précoce) de l'est de la Gaspésie. Les silicoclastites sont plus riches en TR que les carbonates contemporains. Une relation positive entre la teneur en TR et le contenu en aluminosilicates s'observe dans la majorité des échantillons. Bien que pauvres en aluminosilicates, les concrétions diagénétiques ont donné les valeurs les plus élevées en TR. Ces concrétions sont également caractérisées par une importante anomalie négative en europium. Les données minéralogiques, les éléments majeurs et les isotopes stables montrent que la cimentation de calcite à l'origine des concrétions fut rapide et complétée avant d'atteindre la zone de méthanogenèse. Les conditions diagénétiques furent responsables de la remobilisation des TR provenant des sédiments détritiques encaissants et de l'augmentation du contenu en TR dans les concrétions. Le patron des TR est ainsi vu comme un outil potentiel pour reconnaître les lits diagénétiques originant d'environnements géochimiques variés.

[Traduit par la rédaction]

\section{INTRODUCTION}

Rare earth element (REE) distribution in siliciclastic sediments has been mostly centred on provenance studies and crustal evolution (e.g., Taylor and McLennan, 1985; Wronkiewicz and Condie, 1987; Sholkovitz, 1988; McLennan, 1989). Fewer studies have documented REE distribution in carbonate sediment and bioclastic material (Shaw and Wasserburg, 1985; Palmer, 1985; Tlig and M'Rabet, 1985; Wright et al., 1987). REE study of diagenetic carbonates is hampered by the strong speciation of REE for detrital minerals that commonly masks diagenetic signals (Jarvis et al., 1975; McLennan et al., 1979). Nonetheless, many studies have attempted to understand the complex behaviour of REE during diagenesis of a carbonate succession (Nelson, 1987; Banner et al., 1988; Dorobek and Filby, 1988; Schieber, 1988).

Geological Survey of Canada Contribution No. 13292
This contribution presents REE patterns, selected major element geochemistry and mineralogic data for siliciclastic and carbonate lithofacies from the Lower Devonian Upper Gaspé Limestones in their type area, Forillon Peninsula, in eastern Gaspé (Fig. 1). More significantly, the contribution documents the effect of diagenesis on the REE distribution and, in particular, the applicability of REE in recognition of diagenetic beds.

\section{Geological Setting}

The Upper Gaspé Limestones crop out in the Connecticut Valley - Gaspé Synclinorium in the Gaspé Basin, at the eastern end of the Québec segment of the Appalachian orogen (Fig. 1).

The Lower Devonian (Siegenian - earliest Emsian) Upper Gaspé Limestones (Lespérance, 1980) conformably overlie the Silurian-lowermost Devonian Chaleurs Group. They are conformably overlain by the late Early to Middle Devonian 


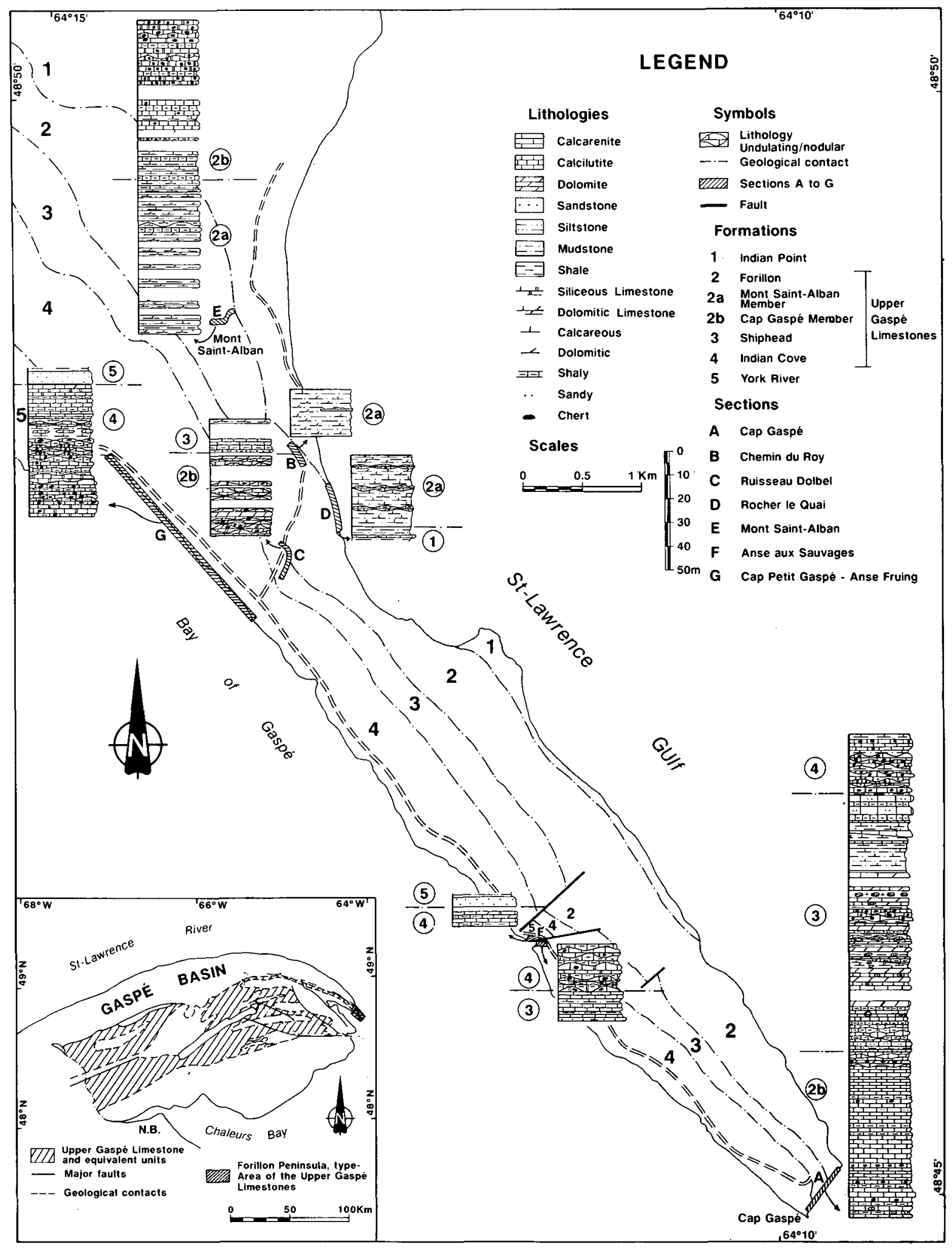

Fig. 1. Geology of the Forillon Peninsula, with location and stratigraphy of the studied sections. Numeral identification of sections (AG) is used as the first digit in sample number in Tables 1 to 4. Modified from Lavoie (1992).

Gaspé Sandstones. The Upper Gaspé Limestones are composed, from base to top, of the Forillon, Shiphead and Indian Cove formations (Figs. 1, 2).

The Forillon Formation is divided into two members; the Mont Saint-Alban and overlying Cap Gaspé members (La- voie 1992; Figs. 1, 2 herein). The Mont Saint-Alban Member is mostly composed of silty mudstones. The Cap Gaspé Member of the Forillon Formation, the Shiphead Formation and the Indian Cove Formation are mostly made up of wavybedded siliceous lime mudstones and wackestones. Pack- 


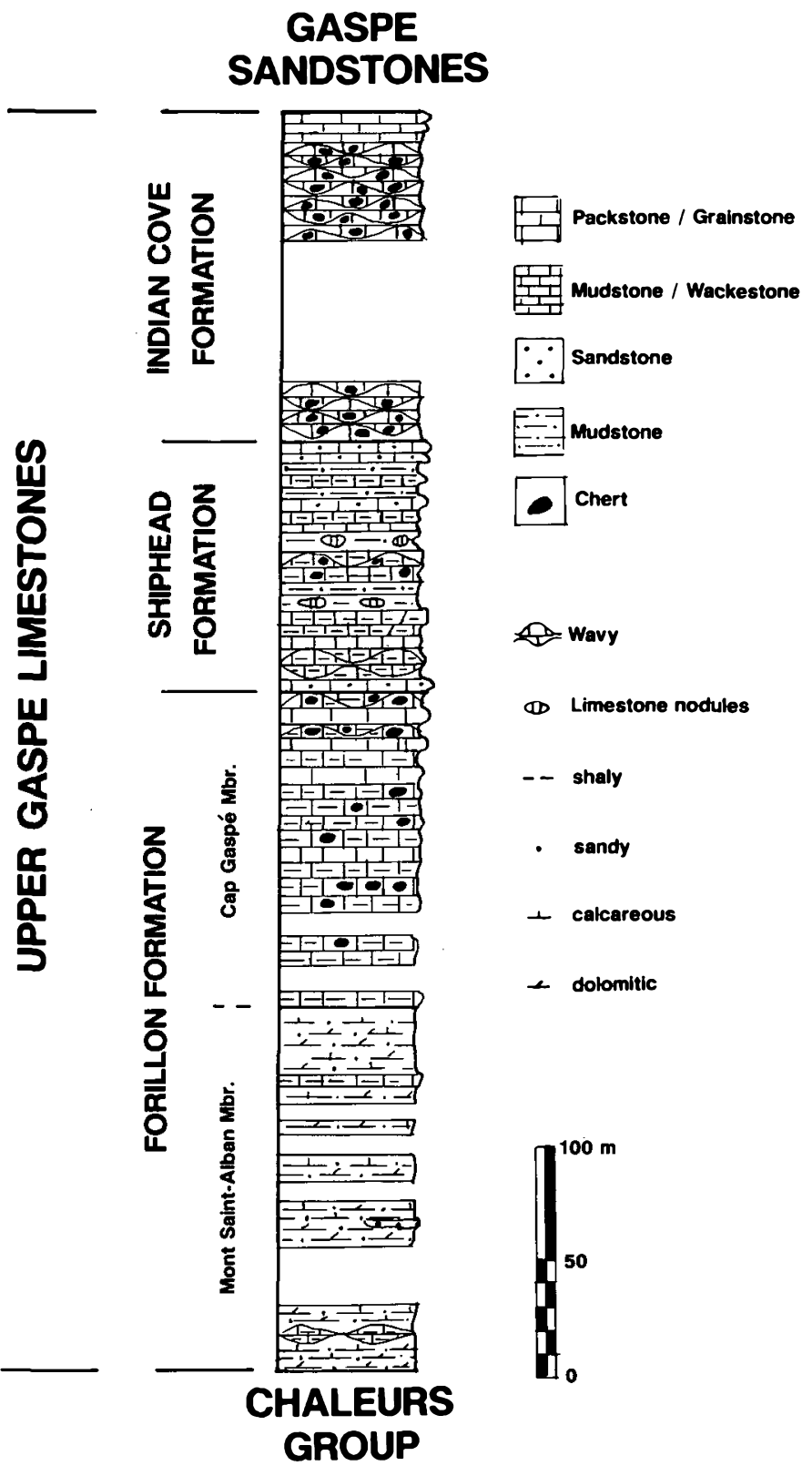

Fig. 2. Composite lithostratigraphic section for the Upper Gaspé Limestones from sections A to $\mathbf{G}$ (Fig. 1), Forillon Peninsula.

stones and grainstones are locally interbedded with the finegrained carbonates. Metre-sized units of siliciclastic mudstones with carbonate concretions are found in the Shiphead Formation.

\section{Methods}

The REE (La, Ce, Nd, Sm, Eu, Tb, Ho, Tm, Yb and Lu) contents of 50 samples were analyzed. Aliquots of $0.1 \mathrm{~g}$ from each sample were sealed in plastic bottles and irradiated under a neutron flux of $5.0 \times 10^{12} \mathrm{n} / \mathrm{cm}^{2} / \mathrm{s}$. La, Nd, Sm, Ho and Lu were counted after 8 days for 5000 s and $\mathrm{Ce}, \mathrm{Eu}, \mathrm{Tb}, \mathrm{Tm}$ and $\mathrm{Yb}$ were counted after 35 days for 10000s with an Ortec ${ }^{\mathrm{tm}}$ ultrapure germanium gamma spectrometer. Precision is better than $5 \%$ for $\mathrm{La}, \mathrm{Ce}, \mathrm{Sm}, \mathrm{Eu}, \mathrm{Tb}, \mathrm{Ho}, \mathrm{Tm}, \mathrm{Yb}$ and $\mathrm{Lu}$ and between 5 and $10 \%$ for Nd. Accuracy was tested against BHVO-1, G-2 and AGV-1 international rock standards. Xray fluorescence analysis for major element geochemistry was done using fused disks made from $5 \mathrm{~g}$ of sample. Insoluble residues (IR) were obtained from reaction with $0.1 \mathrm{~N}$ $\mathrm{HCl}$ for $10 \mathrm{~min}$ at room temperature. Subsamples of IR were analyzed by $\mathrm{X}$-ray diffraction for major mineralogic phases. Sixty-five samples from five carbonate concretions were analyzed for $\delta^{18} \mathrm{O}$ and $\delta^{13} \mathrm{C}$ signatures at the Derry Laboratory (Ottawa-Carleton Geoscience Centre); precision of the data is $\pm 0.1 \%$ for both isotopes.

\section{Petrography and Geochemistry}

The Upper Gaspé Limestones succession in the Forillon Peninsula is composed of four major lithofacies (Lavoie, 1992): (1) prodelta siliciclastic mudstones (Mont Saint-Alban Member), (2) outer shelf siliciclastic mudstones (Shiphead Formation), (3) outer shelf lime muds (all units, except the Mont Saint-Alban Member) and, (4) outer shelf storm layers (all units, except the Mont Saint-Alban Member). The analytical results for samples are grouped under lithofacies type and shown in Tables 1 to 4 and Figures 3 to 6 . Ce content is arbitrarily used (lower right inset in Figures 3 to 6) as representing $R E E$ for the relationship between abundance of REE and total aluminosilicate $\left(\mathrm{Al}^{*}=\mathrm{Al}_{2} \mathrm{O}_{3} / \mathrm{SiO}_{2} \mathrm{X}\right.$ IR\%) in samples.

\section{Prodelta siliciclastic silty mudstones}

These mudstones (Mont Saint-Alban Member, Fig. 2) are silty with fine sand-sized material restricted to laminations and fills of burrows. Grains coarser than clay-sized are composed of angular quartz and subordinate feldspar, the amount of which vary from 15 to $50 \%$ in rock volume. The clayey matrix is partly recrystallized to micro- and pseudospar.

The variability of IR content of the mudstone (Table 1 , Fig. 3) is related to various amounts of diagenetic carbonate in the matrix. From our limited data set, the IR content shows a positive correlation with $\mathrm{Al}_{2} \mathrm{O}_{3} / \mathrm{SiO}_{2}$. The REE content of these fine-grained siliciclastic rocks is progressively depleted (La/Lu: 12.8) from the lightest to the heaviest (Fig. 3) and shows a weakly developed positive correlation with total aluminosilicate in samples (Fig. 3). A slight negative Eu anomaly (average log Eu/Eu*: -0.23) is noted.

\section{Outer shelf siliciclastic mudstones}

Mudstones of the Shiphead Formation (Fig. 2) contain elliptical carbonate concretions (average of $10 \mathrm{~cm} \times 10 \mathrm{~cm} \times$ $15 \mathrm{~cm}$ ) found as scattered bodies along bedding planes. Five concretions were analyzed with one host mudstone. A staining test (Dickson, 1966) revealed no mineralogic zonation in the carbonates. The concretions are composed of non-ferroan microspar cementing a sediment rich in clay, silt-sized quartz, sponge spicules and small bioclasts. From petrographic ob- 
Table 1. REE (in ppm) of prodeltaic muds together with selected major elements and I.R.

\begin{tabular}{|c|c|c|c|c|c|c|c|c|c|c|c|c|c|c|c|c|c|}
\hline E-1 & 27,7 & 13,5 & 7 & 1,9 & 0,04 & 14 & 21 & 12 & 2,4 & 0,46 & 0,33 & n.d. & n.d. & 0,71 & 0,12 & 11,7 & $-0,22$ \\
\hline E-2 & 58,2 & 11,7 & 12,7 & 7,4 & 0,06 & 16 & 31 & 15 & 3,3 & 0,6 & 0,36 & nd. & n.d. & 1,4 & 0,19 & 8,4 & $-0,22$ \\
\hline B4 & 30,7 & 6,9 & 6,3 & 1,9 & 0,75 & 36 & 50 & 26 & 5,4 & 0,99 & 0,68 & n.d. & n.d. & 1,2 & 0,16 & 22,5 & $-0,23$ \\
\hline Average & 43,9 & 10,1 & 9,1 & 4,3 & 0,23 & 20 & 31,8 & 17 & 3,5 & 0,6 & 0,43 & n.d. & n.d. & 1,1 & 0,16 & 12,8 & $-0,23$ \\
\hline
\end{tabular}

$\mathrm{La}_{\mathrm{n}} / \mathrm{Lu}_{\mathrm{n}}$ is the ratio of $\mathrm{La}$ and $\mathrm{Lu}$ normalized to chondrite

$\log \mathrm{Eu} / \mathrm{Eu} u^{*}$ is the Eu anomaly estimated by $\log \left(3 . \mathrm{Eu}_{n} /\left(2 . \mathrm{Sm}_{1}+\mathrm{Tb}_{n}\right)\right)$

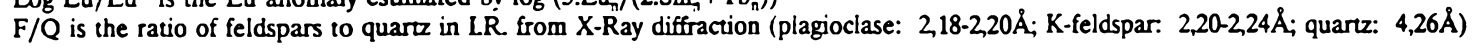

$$
\mathrm{Al}^{\bullet}=\frac{\mathrm{Al}_{2} \mathrm{O}_{3}}{\mathrm{SiO}_{2}} \times I R
$$

n.d.: not detected

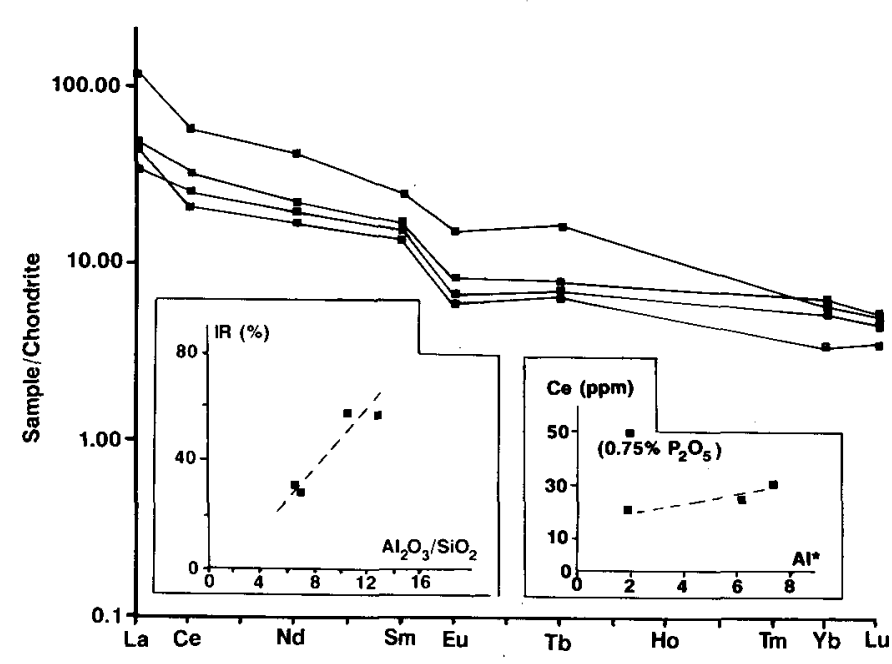

Fig. 3. REE patterns for prodelta siliciclastic mudstones with, inserted (left), the relationship between IR content and $\mathrm{Al}_{2} \mathrm{O}_{3}$ / $\mathrm{SiO}_{2}$ ratio of the samples and (right), the relationship between absolute REE content (represented by $\mathrm{Ce}$ ) and total aluminosilicate in the rock $\left(\mathrm{Al}^{*}\right)$. Data are in Table 1.

servation, the porosity of the concretions at the onset of calcite precipitation averaged $65 \%$. This value argues for initiation of cementation at shallow depths (Curtis et al., 1986). The microspar is low-magnesian (oxide averages $3.01 \%$ ), $\mathrm{Fe}$ - and $\mathrm{Mn}$-poor (oxides average $0.82 \%$ and $0.05 \%$, respectively). REE, major element and IR data from the concretions are from bulk samples because oxygen and carbon isotopes failed to show internal zoning. $\delta^{18} \mathrm{O}$ and $\delta^{13} \mathrm{C}$ variations within individual concretions are only slightly higher than the precision of data ( $\pm 0.1 \%$ for both isotopes). In the whole set of data (65 samples from 5 concretions), $\delta^{18} \mathrm{O}$ averages $-5.0 \%$, whereas $\delta^{13} \mathrm{C}$ averages $+3.0 \%$.

The IR content of the concretions is variable (Table 2 , Fig. 4). It is feldspar-poor and shows a weakly developed negative correlation with $\mathrm{Al}_{2} \mathrm{O}_{3} / \mathrm{SiO}_{2}$. The data show that light and heavy REE in concretions average higher when compared to other lithofacies, the difference being more pronounced for the HREE (Table 2, Fig. 4). No clear relationship is noted between the REE and aluminosilicate content of the concretions. REE patterns are rather flat $(\mathrm{La} / \mathrm{Lu}: 4.4)$ to in one case concave-up (Fig. 4). The REE distribution shows an important negative Eu anomaly (average Log Eu/Eu*: -0.48) which is well developed in all five analyzed concretions. The host mudstone does not show the Eu anomaly and REE distribution is similar to that of the other siliciclastic mudstone lithofacies.

\section{Outer shelf lime mudstones and wackestones}

The micrite matrix of the lime mudstone and wackestone lithofacies shows various degrees of neomorphism to microspar. Siliciclastic components are ubiquitous and represented by abundant $(5-15 \%)$ clay seams with fine-grained quartz silts $(5-10 \%)$. As a rule, siliciclastics are more abundant in the Shiphead Formation. One important characteristic of the lithofacies is the ubiquity of sponge spicules which supplied the silica for the intense silicification of the lithofacies (Lavoie, 1992). Silicification and chertification of the lithofacies are more intense in the Cap Gaspé Member and Indian Cove Formation (Lavoie, 1992).

The IR content of the analyzed samples is highly variable ranging from a low of $1.7 \%$ up to $80 \%$ for the most silicified rock (Table 3, Fig. 5). Resulting from the increase of diagenetic silica, the IR and $\mathrm{Al}_{2} \mathrm{O}_{3} / \mathrm{SiO}_{2}$ correlate negatively in the Cap Gaspé Member and Indian Cove Formation (Fig. 5a,c). The siliciclastic-rich Shiphead Formation is commonly richer in REE as compared to the other two units (Table 3). Nonetheless, absolute values of REE are fairly low but correlate positively with total aluminosilicate, at least for the Cap Gaspé Member and Shiphead Formation (Fig. 5a,b). REE patterns are similar for all three units and are enriched in LREE (La/Lu: 7.7 to 12.4; Table 3). Apart one Shiphead 
Table 2. REE (in ppm) of outer shelf mudstone and concretions together with selected major elements and I.R.

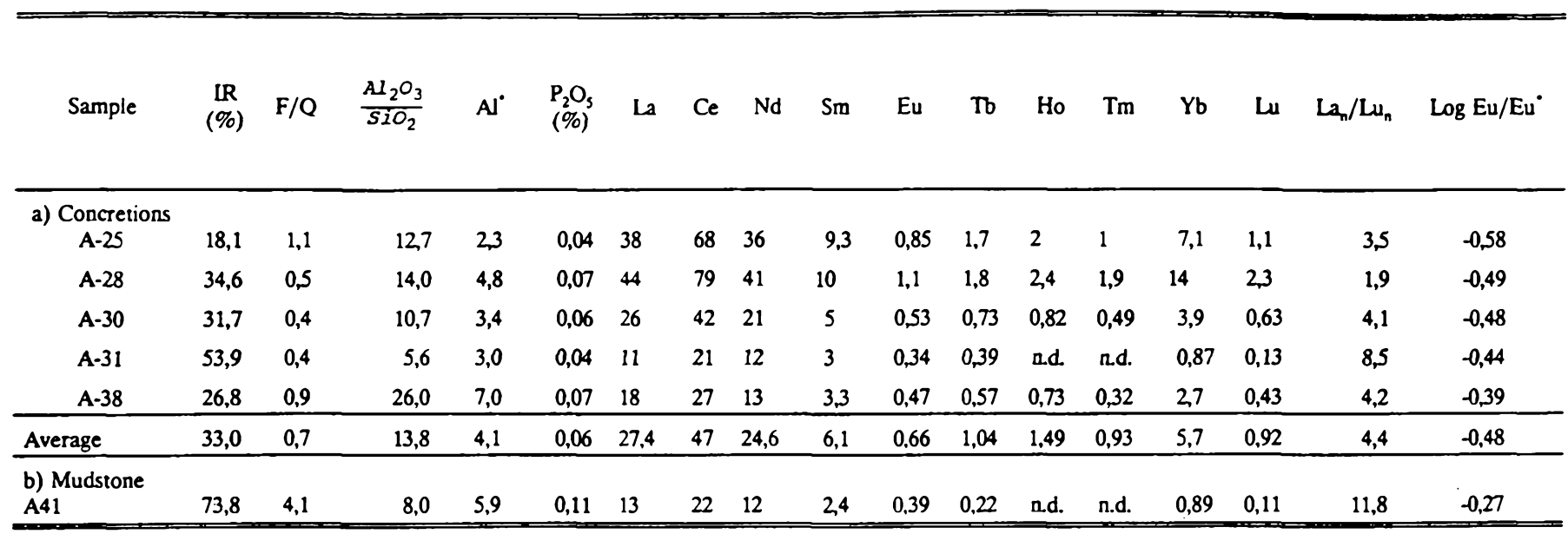

$\mathrm{La}_{\mathrm{n}} / \mathrm{Lu}$ is the ratio of $\mathrm{La}$ and $\mathrm{Lu}$ normalized to chondrite

$\mathrm{Log} \mathrm{Eu} / \mathrm{Eu}^{*}$ is the Eu anomaly estimated by $\log \left(3 . \mathrm{Eu} u_{n} /\left(2 . \mathrm{Sm}_{\mathrm{n}}+\mathrm{Tb}_{n}\right)\right)$

$F / Q$ is the ratio of feldspars to quarz in I.R. from X-Ray diffraction (plagioclase: $2,18-2,20 \AA$; K-feldspar: $2,20-2,24 \AA ;$ quarz: $4,26 \AA$ )

$A I^{\circ}=\frac{\mathrm{Al}_{2} \mathrm{O}_{3}}{\mathrm{SiO}_{2}} \times I R$

nd.: not detected

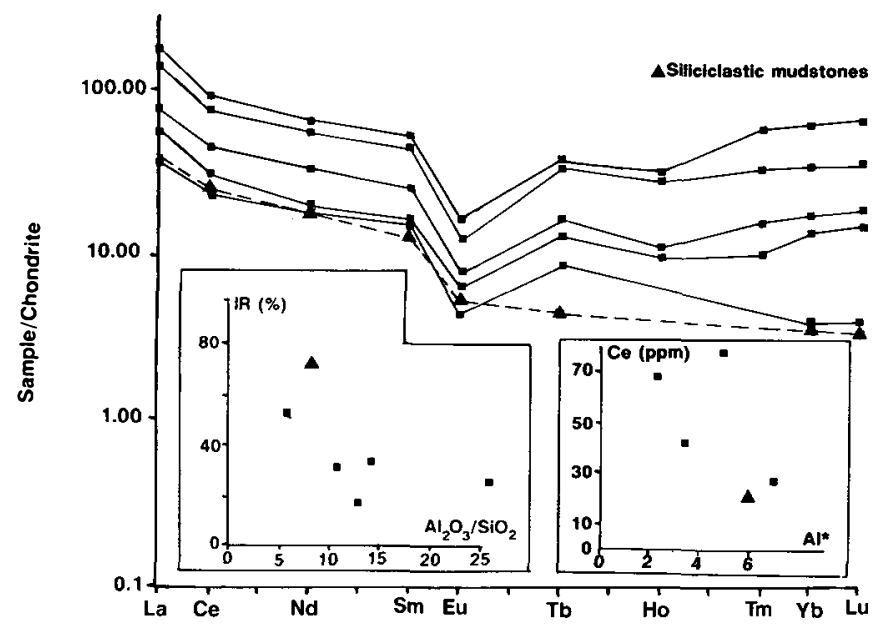

Fig. 4. REE patterns for outer shelf siliciclastic mudstone (dotted line) and carbonate concretions (solid line) with, inserted (left), the relationship between IR content and $\mathrm{Al}_{2} \mathrm{O}_{3} / \mathrm{SiO}_{2}$ ratio of the samples and (right), the relationship between absolute REE content (represented by $\mathrm{Ce}$ ) and total aluminosilicate in the rock (Al*). Data are in Table 2.

sample (A39), no major Eu anomaly is noted (log Eu/Eu*: about -0.23$)$.

\section{Outer shelf packstones / grainstones (storm layers)}

Silt- and sand-sized siliciclastic material constitutes about 5\% of the Cap Gaspé Member and Indian Cove Formation; however, it can reach up to $60 \%$ for some Shiphead samples and averages much higher at around $20 \%$. This material is mostly composed of quartz; plagioclase, K-feldspar and felsic volcanic fragments are mostly restricted to the Shiphead Formation.

The variability in the nature of siliciclastic material is well shown in the IR content and $\mathrm{Al}_{2} \mathrm{O}_{3} / \mathrm{SiO}_{2}$ of these samples (Table 4, Fig. 6), where a positive relationship seems to be developed only for the Shiphead samples. Absolute REE values for the Shiphead samples correlate positively with total aluminosilicate; the relationship is far less clear for the Indian Cove samples. REE patterns are more depleted in HREE for the Cap Gaspé and Indian Cove samples (La/Lu: 11.7 and 21.0 , respectively) when compared with the Shiphead samples $(\mathrm{La} / \mathrm{Lu}: 8.3)$. No significant Eu anomaly is present (average Log Eu/Eu*: -0.20 to -0.25 ).

\section{Discussion}

REE in the Upper Gaspé Limestones lithofacies show an enrichment in LREE compared to HREE (Fig. 7) which is more pronounced for mechanically deposited sediments (siliciclastic and carbonate; La/Lu: 7.7 to 21) than for carbonate concretions (La/Lu: 4.4).

Siliciclastic lithofacies are commonly richer in REE when compared with carbonate lithofacies because of their higher content of REE-enriched aluminosilicates (Haskin $e t$ al., 1968; Piper, 1974; Taylor and McLennan, 1985). This is also the case here; the prodelta and outer shelf siliciclastic muds of the Upper Gaspé Limestones are richer in REE than coeval mechanically deposited carbonates (Fig. 7). In most cases, the absolute abundance of aluminosilicates in rock samples ( $\mathrm{Al}^{*}$ index) controls the content of REE in carbonate lithofacies (Figs. 5, 6). Samples with relatively high IR content but with low $\mathrm{Al}_{2} \mathrm{O}_{3} / \mathrm{SiO}_{2}$ ratio are as $\mathrm{REE}$-depleted as samples having low IR content, a situation related to increas- 
Table 3. REE (ppm) of outer shelf calcilutites together with selected major elements and I.R.

\begin{tabular}{|c|c|c|c|c|c|c|c|c|c|c|c|c|c|c|c|c|c|}
\hline Sample & $\begin{array}{c}\text { IR } \\
(\%)\end{array}$ & $F / Q$ & $\frac{\mathrm{Al}_{2} \mathrm{O}_{3}}{\mathrm{SIO}_{2}}$ & $\mathbf{A l}^{\bullet}$ & $\begin{array}{l}\mathrm{P}_{2} \mathrm{O}_{3} \\
(\%)\end{array}$ & La & ce & Nd & Sm & Eu & Tb & Ho & $\operatorname{Tm}$ & Yb & Lu & $\mathrm{La} / \mathrm{Lu}_{\mathrm{g}}$ & $\mathrm{Log} \mathrm{Eu} / \mathrm{Eu} \mathrm{u}^{\circ}$ \\
\hline a) Cap Gaspe Mbr. & $\begin{array}{l}1,7 \\
45,6 \\
27,7 \\
18,2 \\
11,1 \\
61,7 \\
33 \\
47,7 \\
46,6 \\
28,1 \\
37,8 \\
31,7 \\
80 \\
38,2 \\
\end{array}$ & $\begin{array}{r}2,4 \\
1,6 \\
3,7 \\
6,1 \\
14,5 \\
0,8 \\
6,4 \\
2,2 \\
1,1 \\
12,1 \\
15,9 \\
3,7 \\
0,2 \\
1,0 \\
\end{array}$ & $\begin{array}{r}0 \\
3,3 \\
4,2 \\
8,4 \\
i 9,3 \\
2,9 \\
6,9 \\
2,8 \\
2,4 \\
8,9 \\
11,5 \\
6,6 \\
2,8 \\
4,0 \\
\end{array}$ & $\begin{array}{l}1,5 \\
1,2 \\
1,2 \\
2,1 \\
1,8 \\
2,3 \\
1,3 \\
1,1 \\
3,4 \\
4,3 \\
2,1 \\
2,2 \\
1,5 \\
\end{array}$ & $\begin{array}{l}0,13 \\
0,07 \\
0,14 \\
0,04 \\
0,06 \\
0,04 \\
0,09 \\
0,07 \\
0,02 \\
0,03 \\
0,03 \\
0,04 \\
0,02 \\
0,01 \\
\end{array}$ & $\begin{array}{c}5,3 \\
5,5 \\
5,7 \\
5,9 \\
7 \\
7,4 \\
6,9 \\
5,5 \\
5,4 \\
8,6 \\
11 \\
9,6 \\
6,7 \\
8,3 \\
\end{array}$ & $\begin{array}{l}8,9 \\
9 \\
9,1 \\
8,8 \\
11 \\
11 \\
12 \\
9 \\
9,1 \\
15 \\
21 \\
17 \\
11 \\
13 \\
\end{array}$ & $\begin{array}{c}5,7 \\
4,5 \\
4,7 \\
4,6 \\
5,4 \\
5,6 \\
6 \\
5,2 \\
4,9 \\
7,5 \\
10 \\
8,5 \\
5,8 \\
6,6 \\
\end{array}$ & $\begin{array}{l}1,3 \\
1 \\
0,97 \\
0,87 \\
1,1 \\
1,3 \\
1,4 \\
1,1 \\
1 \\
1,5 \\
2,3 \\
1,7 \\
1,4 \\
1,4 \\
\end{array}$ & $\begin{array}{l}0,29 \\
0,19 \\
0,17 \\
0,17 \\
0,2 \\
0,25 \\
0,25 \\
0,2 \\
0,18 \\
0,27 \\
0,39 \\
0,33 \\
0,28 \\
0,26 \\
\end{array}$ & $\begin{array}{l}0,19 \\
0,13 \\
0,12 \\
\text { nd. } \\
0,13 \\
0,16 \\
0,17 \\
0,16 \\
0,16 \\
0,15 \\
0,27 \\
0,22 \\
0,16 \\
0,18 \\
\end{array}$ & $\begin{array}{l}\text { nd. } \\
\text { nd. } \\
\text { nd. } \\
\text { nd. } \\
\text { nd. } \\
\text { nd. } \\
\text { nd. } \\
\text { nd. } \\
\text { nd. } \\
\text { nd. } \\
\text { nd. } \\
\text { nd. } \\
\text { nd. } \\
\text { nd. }\end{array}$ & $\begin{array}{l}\text { nd. } \\
\text { nd. } \\
\text { nd. } \\
\text { n.d. } \\
\text { n.d. } \\
\text { n.d. } \\
\text { n.d. } \\
\text { n.d. } \\
\text { n.d. } \\
\text { nd. } \\
\text { n.d. } \\
\text { nd. } \\
\text { nd. } \\
\text { nd. }\end{array}$ & $\begin{array}{l}0,36 \\
0,3 \\
0,34 \\
0,33 \\
0,36 \\
0,5 \\
0,57 \\
0,36 \\
0,36 \\
0,57 \\
0,87 \\
0,61 \\
0,5 \\
0,4 \\
\end{array}$ & $\begin{array}{c}0,051 \\
0,058 \\
\text { nd. } \\
\text { nd. } \\
\text { nd. } \\
0,052 \\
0,066 \\
0,058 \\
0,065 \\
0,086 \\
0,15 \\
0,11 \\
0,062 \\
0,064 \\
\end{array}$ & $\begin{array}{c}10,4 \\
9,5 \\
: \\
: \\
14,2 \\
10,5 \\
9,5 \\
8,3 \\
10 \\
7,3 \\
8,7 \\
10,8 \\
12,9 \\
\end{array}$ & $\begin{array}{l}-0,16 \\
-0,22 \\
-0,26 \\
-0,24 \\
-0,22 \\
-0,25 \\
-0,26 \\
-0,26 \\
-0,24 \\
-0,27 \\
-0,21 \\
-0,19 \\
-0,23 \\
\end{array}$ \\
\hline Average & 36.4 & 5,1 & 6.5 & 2 & 0,06 & 7,1 & 11,8 & 6,1 & 1,3 & 0,25 & 0,17 & nd. & n.d. & 0.46 & 0,075 & 10,2 & $-0,23$ \\
\hline $\begin{array}{c}\text { b) Shiphead Fm. } \\
\text { A-19 } \\
\text { A-21 } \\
\text { A-34 } \\
\text { A-39 } \\
\text { F-3 } \\
\end{array}$ & $\begin{array}{l}16,9 \\
46,9 \\
73,9 \\
73,2 \\
76,8 \\
\end{array}$ & $\begin{array}{l}0,3 \\
0,3 \\
0,1 \\
1,5 \\
4,2\end{array}$ & $\begin{array}{c}10 \\
6 \\
1,9 \\
9,3 \\
7,4 \\
\end{array}$ & $\begin{array}{l}1,7 \\
2,8 \\
1,4 \\
6,8 \\
5,7 \\
\end{array}$ & $\begin{array}{l}0,04 \\
0,04 \\
0,03 \\
0,11 \\
0,07 \\
\end{array}$ & $\begin{array}{r}6,4 \\
8,5 \\
3,5 \\
20 \\
16 \\
\end{array}$ & $\begin{array}{c}8,9 \\
14 \\
5,3 \\
40 \\
29 \\
\end{array}$ & $\begin{array}{l}4,6 \\
7,4 \\
2,9 \\
20 \\
14 \\
\end{array}$ & $\begin{array}{l}0,97 \\
1,7 \\
0,64 \\
4,9 \\
3 \\
\end{array}$ & $\begin{array}{l}0,18 \\
0,33 \\
\text { ndd } \\
0,54 \\
0,52\end{array}$ & $\begin{array}{l}0,11 \\
0,21 \\
\text { nd. } \\
0,66 \\
0,37 \\
\end{array}$ & $\begin{array}{l}\text { nd. } \\
\text { nd. } \\
\text { nd. } \\
0,53 \\
\text { nd. }\end{array}$ & $\begin{array}{l}\text { n.d. } \\
\text { n.d. } \\
\text { n.d. } \\
\text { nd. } \\
\text { n.d. }\end{array}$ & $\begin{array}{l}0,38 \\
0,82 \\
0,35 \\
1,7 \\
1,2 \\
\end{array}$ & $\begin{array}{l}\text { nd. } \\
0,12 \\
\text { nd. } \\
0,26 \\
0,19 \\
\end{array}$ & $\begin{array}{l}\dot{7,1} \\
\dot{7,7} \\
8,4\end{array}$ & $\begin{array}{c}-0,21 \\
-0,21 \\
- \\
-0,46 \\
-0,26\end{array}$ \\
\hline Average & 57,5 & 1,3 & 6,9 & 3,7 & 0,06 & 10,9 & 19,4 & 9,8 & 2,2 & 0,39 & 0,34 & & nd. & 0,89 & 0,19 & 7.7 & $-0,29$ \\
\hline $\begin{array}{c}\text { c) Indian Cove Fm. } \\
\text { A-46 } \\
\text { A.50 } \\
\text { F.10 } \\
\text { G.3 } \\
\text { G.14 } \\
\text { G.20 } \\
\text { G.22 } \\
\text { G-25 }\end{array}$ & $\begin{array}{c}68,5 \\
43,1 \\
26,2 \\
8 \\
65,2 \\
44,9 \\
46,1 \\
31,3 \\
\end{array}$ & $\begin{array}{l}0,2 \\
0,5 \\
0,5 \\
3,7 \\
0,1 \\
0,5 \\
2 \\
2,5\end{array}$ & $\begin{array}{r}1,9 \\
2,8 \\
3,6 \\
47,0 \\
1,8 \\
1,8 \\
3,9 \\
2,4\end{array}$ & $\begin{array}{c}1,3 \\
1,2 \\
1 \\
3,7 \\
1,1 \\
40,8 \\
1,8 \\
0,8\end{array}$ & $\begin{array}{l}0 \\
0,03 \\
0,01 \\
0,02 \\
0,02 \\
0,02 \\
0,01 \\
0,03\end{array}$ & $\begin{array}{c}5,6 \\
8,7 \\
11 \\
6,7 \\
7,2 \\
6,7 \\
11 \\
7,2\end{array}$ & $\begin{array}{c}8,2 \\
11 \\
13 \\
9,1 \\
9,7 \\
9,3 \\
15 \\
9,3\end{array}$ & $\begin{array}{l}5 \\
6,8 \\
9,9 \\
5,4 \\
6,7 \\
5,6 \\
8,9 \\
5,7\end{array}$ & $\begin{array}{l}1,1 \\
1,2 \\
1,6 \\
1,1 \\
1,2 \\
1,1 \\
1,8 \\
1,2\end{array}$ & $\begin{array}{l}0,19 \\
0,24 \\
0,29 \\
0,23 \\
0,23 \\
0,21 \\
0,33 \\
0,22\end{array}$ & $\begin{array}{l}0,16 \\
0,14 \\
0,17 \\
0,15 \\
0,15 \\
0,15 \\
0,22 \\
0,16\end{array}$ & $\begin{array}{l}\text { nd. } \\
\text { nd. } \\
\text { nd. } \\
\text { nd. } \\
\text { nd. } \\
\text { nd. } \\
\text { nd. } \\
\text { nd. }\end{array}$ & $\begin{array}{l}\text { n.d. } \\
\text { n.d. } \\
\text { nd. } \\
\text { nd. } \\
\text { nd. } \\
\text { nd. } \\
\text { nd. } \\
\text { n.d. }\end{array}$ & $\begin{array}{l}0,55 \\
0,42 \\
0,44 \\
0,36 \\
0,36 \\
0,36 \\
0,59 \\
0,39\end{array}$ & $\begin{array}{l}0,075 \\
0,063 \\
0,054 \\
0,051 \\
0,058 \\
0,092 \\
0,062\end{array}$ & $\begin{array}{r}7,5 \\
- \\
17,5 \\
12,4 \\
14,1 \\
11,6 \\
12,0 \\
11,6\end{array}$ & $\begin{array}{l}-0,27 \\
-0,19 \\
-0,22 \\
-0,18 \\
-0,21 \\
-0,22 \\
-0,23 \\
-0,24\end{array}$ \\
\hline Average & 41,7 & 1,3 & 8,2 & 1,5 & 0,02 & 8,0 & 10,6 & 6,8 & 1,3 & 0,24 & 0,16 & nd. & n.d. & 0,43 & 0,065 & 12,4 & $-0,22$ \\
\hline
\end{tabular}

$\mathrm{La} / \mathrm{Lu}$ is the ratio of $\mathrm{Lia}$ and $\mathrm{Lu}$ normalized to chondrite

$\mathrm{Log} \mathrm{Eu} / \mathrm{Eu}^{\circ}$ is the Eu anomaly estimated by $\log \left(3 . \mathrm{Eu}_{\mathrm{a}} /\left(2 \mathrm{Sm}+\mathrm{Tb}_{\mathrm{n}}\right)\right)$

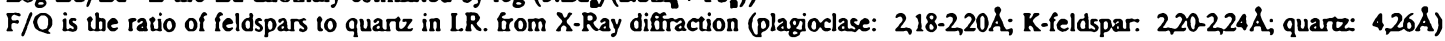

$$
\begin{aligned}
& \mathrm{Al} \cdot=\frac{\mathrm{Al}_{2} \mathrm{O}_{3}}{\mathrm{SiO}_{2}} \times I R \\
& \text { n.d.: not detected }
\end{aligned}
$$

ing abundance of REE-poor diagenetic silica (Piper, 1974). REE-rich phosphatic material (Wright et al., 1987; Banner et al., 1988), organic or not, is a very minor component in all samples $\left(\mathrm{P}_{2} \mathrm{O}_{5}\right.$ concentration generally less than $0.1 \%$; Tables 1 to 4$)$, hence its REE contribution is considered to be of the same relative minor magnitude.

Marine carbonates commonly display negative or less commonly positive Ce anomalies (Shaw and Wasserberg, 1985; Palmer, 1985; Banner et al., 1988). Some of the outer shelf lime mudstones and wackestones of the Cap Gaspé Member and Indian Cove Formation show a slight negative Ce anomaly; however, most of the mechanically deposited carbonates of the Upper Gaspé Limestones do not. Negative $\mathrm{Ce}$ anomalies have been related to the removal of insoluble $\mathrm{Ce}^{+4}$ from oxidizing marine environment (Elderfield and Graves, 1982; Palmer, 1985; Banner et al., 1988). The absence of a significant $\mathrm{Ce}$ anomaly is not restricted to Lower
Devonian carbonates of Gaspé as it has been documented elsewhere (Jarvis et al., 1975; Parekh et al., 1977; Graf, 1984; Wright et al., 1987). It is explained by either (1) the absence of such an anomaly in the lower Paleozoic oceans (Wright et al., 1987), or (2) the variable influence of detrital material either shortly after deposition or during later remobilization during diagenesis, or (3) an analytical problem where REE in aluminosilicates mask the anomaly (Banner $e t$ al., 1988).

Diagenetic concretions grown on the outer shelf are commonly similar in aluminosilicate and phosphatic components to mechanically deposited lithofacies. Our data set shows that concretions are characterized by the highest concentrations in REE of our analyzed samples (Fig. 7). It is clear that the high REE content in the concretions is not related either to the amount of aluminosilicate or anomalously high apatite content (Table 2, Fig. 4).

The recycling of REE from detrital sediments into pore 

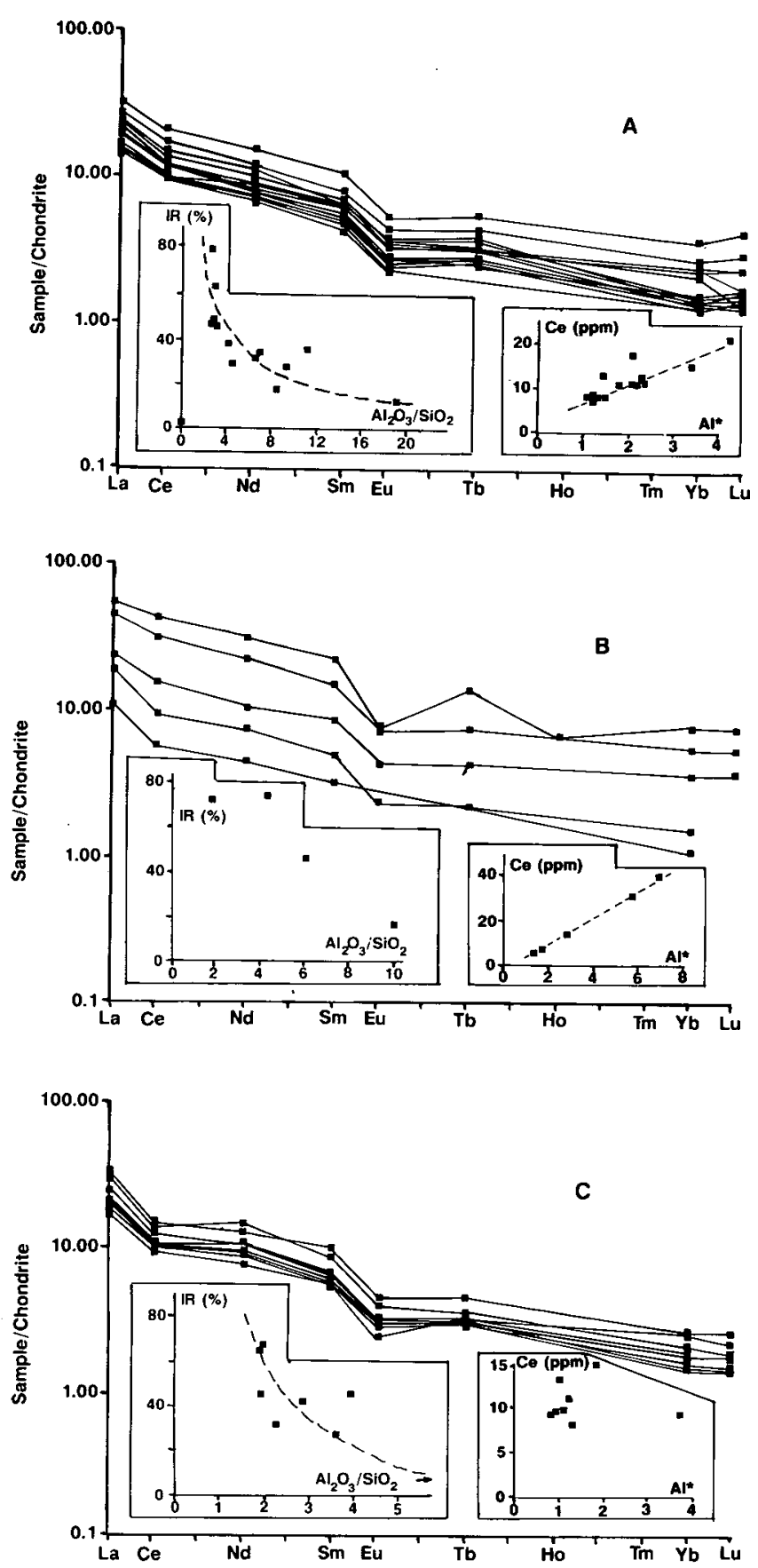

Fig. 5. REE patterns for outer shelf mudstones / wackestones with, inserted (left), the relationship between IR content and $\mathrm{Al}_{2} \mathrm{O}_{3}$ / $\mathrm{SiO}_{2}$ ratio of the samples and (right), the relationship between absolute REE content (represented by $\mathrm{Ce}$ ) and total aluminosilicate in the rock $\left(\mathrm{Al}^{*}\right)$. (A) Cap Gaspé Member (Forillon Formation), (B) Shiphead Formation and (C) Indian Cove Formation. Data are in Table 3.

waters is documented from modern settings, resulting in 10 to 50 times enhanced REE concentrations in pore waters compared to local seawater values (Elderfield and Sholkovitz, 1987; Sholkovitz, 1988). Remobilization of REE from detrital minerals into various diagenetic carbonates is also documented from the rock record (McLennan et al., 1979; Banner et al., 1988; Schieber, 1988). From these considerations, it is probable that transfer of REE from aluminosilicates of the host mudstones to the pore waters and ultimately into precipitating calcites occurred similarly for the Lower Devonian concretions of the Gaspé basin. This resulted in higher REE content in concretions compared with that of the host mudstones (Fig. 4).

A significant negative Eu anomaly (Table 2, Figs. 4, 7) is present in the concretions; less significant Eu anomalies are also detected in other lithofacies (Tables 1, 3, 4; Figs. 3, 5-7). The concentrations of $\mathrm{Eu}$ in the concretions are commonly higher than those of the host mudstones (Table 2). Consequently, the negative Eu anomaly seemingly results from a relatively less efficient diagenetic remobilization of Eu when compared to the other REE; this could possibly be in part related to the strong speciation of Eu for plagioclase (McLennan, 1989) that prevented efficacious remobilization. However, from XRD, plagioclase is a very minor component of IR (F/Q ratio on Tables 1 to 4 and unpublished data).

$\mathrm{Eu}^{+2}$ is generally not complexed in pore waters and is more soluble than other REE (Sverjensky, 1984). Conditions for reducing $\mathrm{Eu}^{+3}$ to $\mathrm{Eu}^{+2}$, which could then substitute for $\mathrm{Ca}$ in calcite, are met in reducing, alkaline environments (Sverjensky, 1984; Brookins, 1989); these conditions are met in anoxic pore water of marine sediments where diagenetic carbonate precipitation is forming concretions (Gautier, 1982; Curtis et al., 1986). Interestingly, concretions that grew in a strongly reducing environment (methanogenic zone) are characterized by a positive Eu anomaly (Tassé and Bergeron, unpublished data).

Although the exact mechanism for the lack of efficacious Eu remobilization is unknown, it could have been related to (1) local mineral-fluid reactions related to chemical gradients in pore waters (Tassé and Bergeron, 1990), (2) early complexation of the $\mathrm{Eu}^{+2}$ during sulphate reduction with either chloride or sulphate (Graf, 1984; Brookins, 1989; Tassé and Bergeron, 1990), or (3) the lack of strongly reducing conditions.

The low concentrations of $\mathrm{Fe}$ and $\mathrm{Mn}$ in the concretions (see above) could either be related to the lack of these elements in the diagenetic fluids or to the halt of calcite precipitation prior to reaching the strongly reducing methanogenic zone. The early formation of the concretions is supported by stable isotopes; the $\delta^{13} \mathrm{C}$ signature of the concretions (average $+3.0 \%$ ) is close to that of marine calcite (average of $+1.5 \%$ from brachiopods; Lavoie, 1993). There is no evidence for any significant input of isotopically heavy $\mathrm{CO}_{2}$ that would have been released from methanogenic processes. Similarly, $\delta^{18} \mathrm{O}$ data for the concretions (average $5.0 \%$ ) indicate a near to normal Early Devonian marine isotopic signature for the Gaspé basin (average -3.0\% from brachiopods; Lavoie, 1993). This, coupled with the absence of pyrite or Fe-rich carbonate, suggests that the concretions grew in a sediment with an important inherited marine carbonate fraction and that the growth was mostly concluded in 
Table 4. REE (ppm) of storm layers together with selected major elements and I.R.

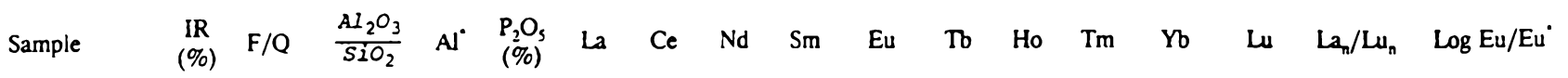

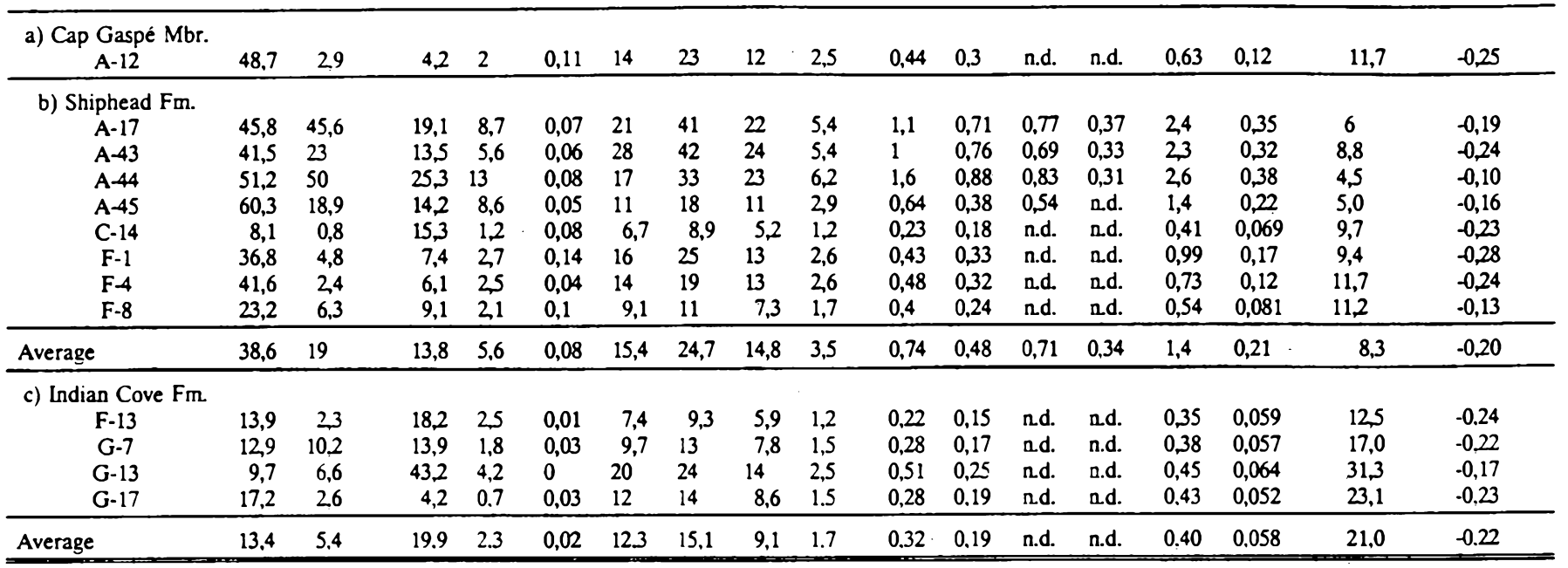

$\mathrm{La}_{n} / \mathrm{Lu}_{n}$ is the ratio of $\mathrm{La}$ and $\mathrm{Lu}$ normalized to chondrite

$\mathrm{Log} \mathrm{Eu} / \mathrm{Eu}^{*}$ is the Eu anomaly estimated by $\log \left(3 . \mathrm{Eu}_{\mathrm{u}} /\left(2 . \mathrm{Sm}_{\mathrm{n}}+\mathrm{Tb}_{\mathrm{n}}\right)\right)$

$F / Q$ is the ratio of feldspars to quarz in I.R. from X-Ray diffraction (plagioclase: $2,18-2,20 \AA$ : K-feldspar: 2,20-2.24 $\AA$; quarz: $4,26 \AA$ )

$$
A I^{\bullet}=\frac{\mathrm{Al}_{2} \mathrm{O}_{3}}{\mathrm{SiO}_{2}} \times I R
$$

n.d.: not detected
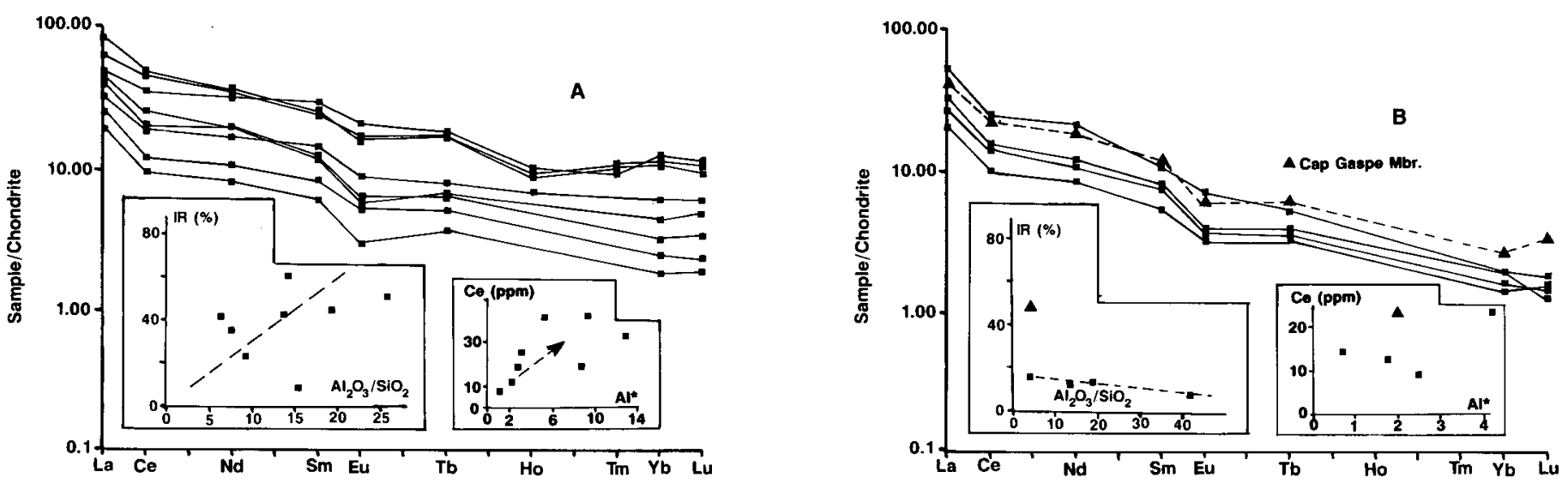

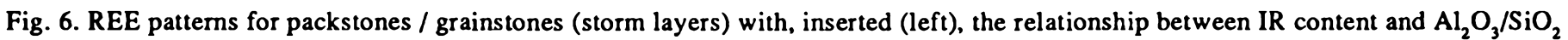
ratio of the samples and (right), the relationship between absolute REE content (represented by Ce) and total aluminosilicate in the rock $\left(\mathrm{Al}{ }^{*}\right)$. (A) Shiphead Formation and (B) Indian Cove Formation and Cap Gaspé Member (Forillon Formation; dotted line). Data are in Table 4.

a very shallow anoxic environment prior to reaching the methanogenic zone and before any significant thermal fractionation of the oxygen isotopes occurred.

The REE patterns of concretions from the Upper Gaspé Limestones is important as these patterns are significantly different between diagenetic products and mechanically deposited carbonate sediments. Interestingly, the A-39 sample (Table 3), classified on field observation as a mechanically deposited outer shelf mud, shows a REE distribution more similar in its absolute content and Eu anomaly to the carbonate concretions. It seems reasonable to think that diagenetic processes responsible for raising the REE content of the concretions also played some major role in the history of that bed. This wavy-bedded and laterally continuous horizon, occurring in the concretion-bearing outer shelf siliciclastic mudstone pile, is now seen as a laterally continuous diagenetic bed. Therefore, REE patterns are considered to be a significant new tool for the recognition of diagenetic beds 


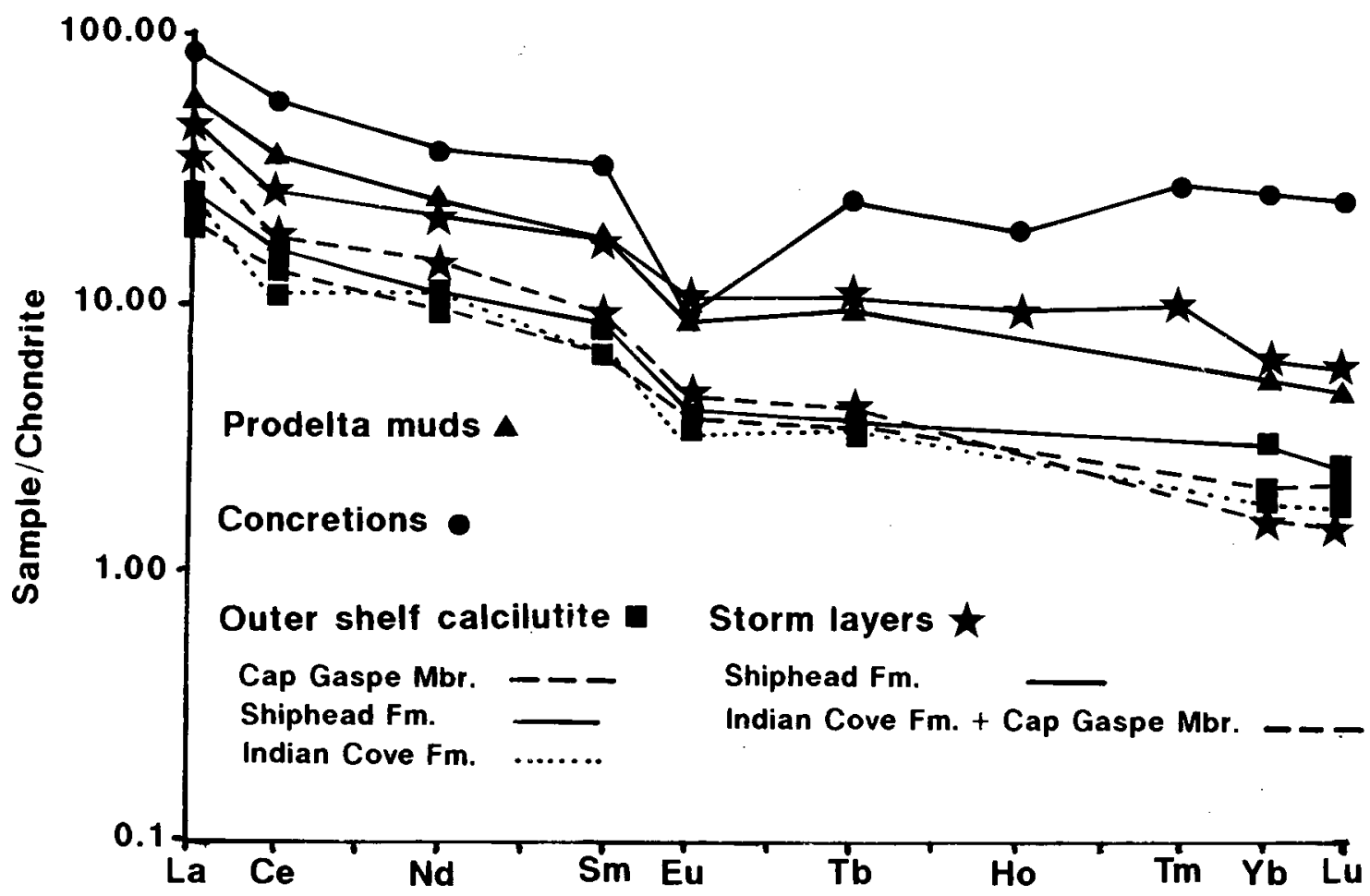

Fig. 7. Average REE patterns for the Lower Devonian lithofacies of the Upper Gaspé Limestones.

that could go unnoticed using conventional geochemical methods such as stable isotopes and major and minor elements.

\section{Conclusions}

Rare earth element distribution, selected major element geochemistry and the content and nature of insoluble residues in a Lower Devonian mixed carbonate-siliciclastic succession show that:

(1) siliciclastic lithofacies are richer in REE than coeval carbonate lithofacies;

(2) in most cases, REE in carbonates correlate positively with total aluminosilicate;

(3) carbonate concretions, even if poor in aluminosilicates, are characterized by the highest absolute content of REE. They are also remarkably different from sedimentary lithofacies in their significant negative Eu anomaly;

(4) diagenesis in the shallow anoxic geochemical environment, prior to the methanogenic zone, resulted in the formation of carbonate concretions that are remarkably different in REE content when compared to encasing mudstones and coeval mechanically deposited lithologies;

(5) REE distribution in limestones of carbonate successions can be used as a tool for identification of diagenetic beds, in particular if diagenetic growth stopped before reaching the strongly reducing methanogenic environment;

(6) finally, diagenetic history of a rock succession has to be seriously assessed when studying REE distribution in sediments.

\section{ACKNOWLEDGEMENTS}

This study was made possible through the efforts of all the laboratory staff at the Québec Geoscience Centre and their help is gratefully acknowledged. Many thanks are due to Parks Canada and their staff at Forillon that allowed and facilitated our work in this Canadian national park. N. Tassé did initial critical reading of the manuscript. Subsequent clarifications and improvements were suggested by journal reviewers J.A. Winchester and M.P. Atherton. Their comments and suggestions are much appreciated.

BANNER, J.L., HANSON, G.N., and Meyers, W.J. 1988. Rare earth elements and $\mathrm{Nd}$ isotopic variations in regionally extensive dolomites from the Burlington-Keokuk Formation (Mississippian): implications for REE mobility during carbonate diagenesis. Journal of Sedimentary Petrology, 58, pp. 415 432.

Brookins, D.G. 1989. Aqueous geochemistry of rare earth elements. In Geochemistry and mineralogy of rare earth elements. Edited by B.R. Lipin and G.A. McKay. Mineralogical Society of America, Reviews in Mineralogy, 21, pp. 201225.

Curtis, C.D., Coleman, M.L., and Love, L.G. 1986. Pore water evolution during sediment burial from isotopic and mineral chemistry of calcite, dolomite and siderite concretions. Geochemica et Cosmochemica Acta, 50, pp. 2321-2334.

Dickson, J.A.D. 1966. Carbonate identification and genesis as revealed by staining. Journal of Sedimentary Petrology, 36, pp. 491-505.

Dorobek, S.L. and Filby, E.H. 1988. Origin of dolomites in a downslope biostrome, Jefferson Formation (Devonian), cen- 
tral Idaho: evidence from REE pattems, stable isotopes and petrography. Bulletin of Canadian Petroleum Geology, 36. pp. 202-215.

Elderfield, H. and Graves, M.J. 1982. The rare earth elements in seawater. Nature, 296, pp. 214-219.

Elderfield, H. and Sholkovitz, E.R. 1987. Rare earth elements in the pore waters of reducing nearshore sediments. Earth and Planetary Science Letters, 82, pp. 280-288.

GAUTIER, D.L. 1982. Siderite concretions: indicators of early diagenesis in the Gammon Shale (Cretaceous). Journal of Sedimentary Petrology, 52, pp. 859-871.

GrAF, J.L., Jr. 1984. Effects of Mississippi Valley-type mineralization on REE patterns of carbonate rocks and minerals, Viburnum Trend, southeast Missouri. Journal of Geology, 92. pp. 307-324.

Haskin, L.A., Haskin, M.A., Frey, F.A., and Wildeman, T.R. 1968. Relative and absolute terrestrial abundance of the rare earths. In Origin and distribution of the elements. Edited by L.H. Ahrens. Pergamon, Oxford, pp. 889-912.

JARvis, J.C., WILDEMAN, T.R., and BANKS, N.G. 1975. Rare earths in the Leadville Limestones and its marble derivates. Chemical Geology, 16, pp. 27-37.

LAvore, D. 1992. Lower Devonian facies in Forillon Peninsula, eastern Gaspé: A storm-influenced, carbonate outer shelf. Bulletin of Canadian Petroleum Geology, 40, pp. 303-320.

1993. Early Devonian marine isotopic signatures: Brachiopods from the Upper Gaspé Limestones, Gaspé Peninsula, Québec, Canada. Journal of Sedimentary Petrology, 63, No. 4.

Les pérance, P.J. 1980. Calcaires supérieurs de Gaspé. Les airestypes et le prolongement vers l'ouest. Ministère de l'Énergie et des Ressources du Québec, DPV-595.

McLennan, S.M. 1989. Rare earth elements in sedimentary rocks: influence of provenance and sedimentary processes. In Geochemistry and mineralogy of rare earth elements. Edited by B.R. Lipin and G.A. McKay. Mineralogical Society of America, Reviews in Mineralogy, 21, pp. 169-200.

McLennan, S.M., Fryer, B.J., and Young, G.M. 1979. The geochemistry of the carbonate-rich Espanola Formation (Huronian) with an emphasis on the rare earth elements. Canadian Journal of Earth Sciences, 16, pp. 230-239.

Nelson, K.L. 1987. Geochemical evaluation of diagenetic processes in a deep-water carbonate. Chemical Geology, 64, pp. 239-258.
Palmer, M.R. 1985. Rare earth elements in foraminifera tests. Earth and Planetary Science Letters, 73, pp. 285-298.

Parekh, P.P., Moller, P., Dulski, P., and BausCh, W.M. 1977. Distribution of trace elements between carbonate and noncarbonate phases of limestones. Earth and Planetary Science Letters, 34, pp. 39-50.

PIPER, D.Z. 1974. Rare earth elements in the sedimentary cycle: a summary. Chemical Geology, 14, pp. 285-304.

SChIEBER, J. 1988. Redistribution of rare-earth elements during diagenesis of carbonate rocks from the Mid-Proterozoic Newland Formation, Montana, U.S.A. Chemical Geology, 69, pp. 111-126.

Shaw, H.F. and WAsserbuRG, G.J. 1985. Sm-Nd in marine carbonates and phosphates: Implications for $\mathrm{Nd}$ isotopes in seawater and crustal ages. Geochemica et Cosmochemica Acta, 49, pp. 503-518.

Sholkovitz, E.R. 1988. Rare earth elements in the sediments of the North Atlantic ocean, Amazon delta, and east China sea: reinterpretation of terrigenous input patterns to the ocean. American Journal of Science, 288, pp. 236-281.

SVERJENSKY, D.M. 1984. Europium redox equilibrium in aqueous solutions. Earth and Planetary Science Letters, 67, pp. 70-78.

TASSÉ, N. and BERGERON, M. 1990. Geochemistry of REE in carbonates replacing sulfate evaporites (Lower Ordovician Beekmantown Group. St. Lawrence Lowlands, Quebec, Canada). International Association of Sedimentologists, 13th International Sedimentological Congress, Nottingham, United Kingdom. Abstracts of posters volume, pp. 211-212.

TAYLOR, S.R. and MCLENNAN, S.M. 1985. The continental crust: its composition and evolution. Blackwell Scientific, Oxford, England, 312 p.

TLIG, S. and M'RABET, A. 1985. A comparative study of the Rare Earth Elements (REE) distribution within the Lower Cretaceous dolomites and limestones of central Tunisia. Sedimentology, 32, pp. 897-907.

Wright, J., Schrader, H., and Tolser, W.T. 1987. Paleoredox variations in ancient oceans recorded by rare earth elements in fossil apatite. Geochemica et Cosmochemica Acta, 51, pp. 631-644.

WronkIEWICZ, D.J. and CONDIE, K.C. 1987. Geochemistry of Archean shales from the Witwatersrand Supergroup. South Africa - source area, weathering and provenance. Geochemica et Cosmochemica Acta, 51, pp. 2401-2416. 